\title{
Grain-Size Analysis of Hurricane-Induced Event Beds in a New England Salt Marsh, Massachusetts, USA
}

\author{
Authors: Castagno, Katherine A., Donnelly, Jeffrey P., and Woodruff, \\ Jonathan D.
}

Source: Journal of Coastal Research, 37(2) : 326-335

Published By: Coastal Education and Research Foundation

URL: https://doi.org/10.2112/JCOASTRES-D-19-00159.1

BioOne Complete (complete.BioOne.org) is a full-text database of 200 subscribed and open-access titles in the biological, ecological, and environmental sciences published by nonprofit societies, associations, museums, institutions, and presses.

Your use of this PDF, the BioOne Complete website, and all posted and associated content indicates your acceptance of BioOne's Terms of Use, available at www.bioone.org/terms-of-use.

Usage of BioOne Complete content is strictly limited to personal, educational, and non - commercial use. Commercial inquiries or rights and permissions requests should be directed to the individual publisher as copyright holder.

BioOne sees sustainable scholarly publishing as an inherently collaborative enterprise connecting authors, nonprofit publishers, academic institutions, research libraries, and research funders in the common goal of maximizing access to critical research. 


\title{
Grain-Size Analysis of Hurricane-Induced Event Beds in a New England Salt Marsh, Massachusetts, USA
}

\author{
Katherine A. Castagno $^{\dagger *}$, Jeffrey P. Donnelly ${ }^{\ddagger}$, and Jonathan D. Woodruff ${ }^{\S}$ \\ ${ }^{\dagger}$ Department of Marine and Environmental Sciences \\ Marine Science Center \\ Northeastern University \\ Department of Geology and Geophysics \\ Woods Hole Oceanographic Institution \\ Woods Hole, MA 02543, U.S.A.
}

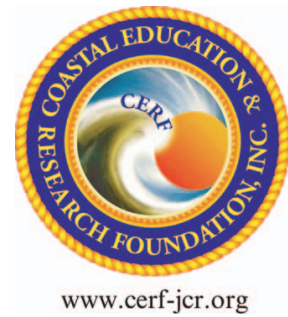

Nahant, MA 01908, U.S.A.

${ }^{\S}$ Department of Geosciences

University of Massachusetts

Amherst, MA 01003, U.S.A.

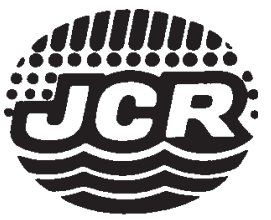

www.JCRonline.org

\begin{abstract}
Castagno, K.A.; Donnelly, J.P., and Woodruff, J.D., 2021. Grain-size analysis of hurricane-induced event beds in a New England salt marsh, Massachusetts, USA. Journal of Coastal Research, 37(2), 326-335. Coconut Creek (Florida), ISSN 0749-0208.

Tropical cyclones pose a growing threat to coastal infrastructure and livelihood. Because instrumental and historic records are too short to help us understand interactions between tropical cyclones and climate on a longer scale, proxy records are the only means for reconstructing millennia of tropical cyclone impacts. This study determines grain-size trends in storm-induced overwash deposits along a transect of sediment cores from a salt marsh in Mattapoisett, Massachusetts, to characterize sorting trends and compare deposits associated with individual storms. The overwash deposits preserved within the high-marsh peat provide a record spanning the last two millennia. Building on a 2010 study, a different approach was used to accurately determine the grain-size distribution of overwash deposits from cores in a transect running perpendicular to the adjacent sandy/gravely barrier. Although maximum grain-size values are expected to decrease as distance from the barrier increases, not all event deposits that were studied follow this trend within uncertainty. Analysis of the storm event beds reveal a significant difference in settling trends between historic and prehistoric deposits, with historic deposits largely displaying landward-fining trends and prehistoric deposits largely displaying landward-coarsening trends. This suggests changes in the hydrodynamic or that geomorphic regime may have altered the way in which storm beds were deposited at this site. This new in-depth, transect-based approach has utility for improving the accuracy of future storm reconstructions, particularly for events for which no historic record exists.
\end{abstract}

ADDITIONAL INDEX WORDS: Tropical cyclones, sediment transport, paleotempestology.

\section{INTRODUCTION}

As coastal population continues to grow in both size and wealth, hurricanes pose a growing threat to livelihood and infrastructure along the coast. Recent research has explored the influence of a changing climate on hurricane frequency, intensity, genesis location, and track. Whereas most assessments agree that an increase in sea-surface temperatures should increase the intensity of tropical cyclones (Emanuel, 2008; Holland and Webster, 2007; Sobel et al., 2016; Walsh et $a l ., 2016)$, natural variability in climate and tropical cyclones, as well as several confounding factors, complicate our understanding of the connections between hurricanes and climate. Sobel et al. (2016) suggest that, historically, aerosol cooling may have dampened the intensifying effect of greenhouse gas forcing, but increased greenhouse gas emissions may eventually overtake this dampening, further increasing future hurricane intensity. Research into the historic and prehistoric North Atlantic hurricane record provides the opportunity to

DOI: 10.2112 /JCOASTRES-D-19-00159.1 received 21 October 2019; accepted in revision 27 August 2020; corrected proofs received 3 November 2020.

*Corresponding author: kcastagno@coastalstudies.org

${ }^{\circ}$ Coastal Education and Research Foundation, Inc. 2021 further understand future impacts of climate change on these destructive events.

Quantitative tropical cyclone records for the entire Atlantic basin date back to the 1850s (Jarvinen and Caso, 1978; Landsea and Franklin, 2013; McAdie et al., 2009), making it the most temporally comprehensive tropical cyclone dataset, though an observational bias exists prior to the advent of satellite data in the 1960s. Historic records for the Atlantic extend as far back as $1492 \mathrm{CE}$ (Ludlum, 1963); in New England, the historic record extends as far back as $1620 \mathrm{CE}$ (Boose, Chamberlin, and Foster, 2001). Because instrumental and historic records are too short to understand interactions between tropical cyclones and climate on a longer (multidecadal to centennial to millennial) scale, proxy records provide valuable insights into climactic influences and are the only means for reconstructing millennia of tropical cyclone impacts.

Storm-induced overwash deposits in coastal ponds and salt marshes have been used to augment understanding of hurricane strikes in SE New England (Boldt et al., 2010; Donnelly et al., 2015; Donnelly et al., 2001; Woodruff et al., 2008). Intense storms can produce storm surge and wave heights significant enough to overtop sandy barriers, transporting and depositing coarse sediment in deep coastal lakes and lagoons or on top of salt marsh peat. This overwash is then 

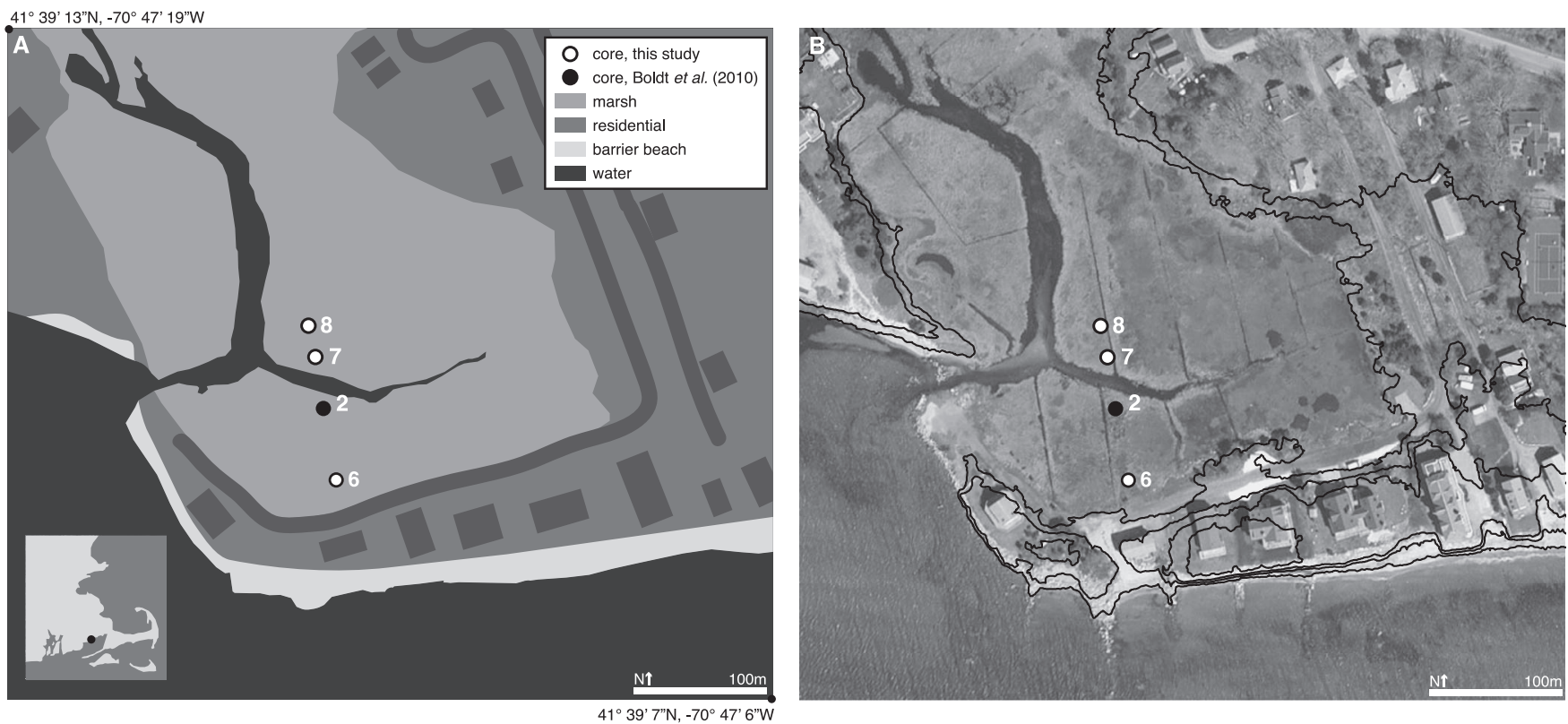

Figure 1. (A) Schematic interpretation of the study area, including location of study cores (indicated by numbers). The barrier is approximately $1-2.5 \mathrm{~m}$ in elevation. (B) Aerial photo of the study area with $0.5-\mathrm{m}$ contours.

covered by finer-grained material or peat, preserving the storm event as a stratigraphically distinct, allochthonous layer. Orson and Howes (1992) and Warren and Niering (1993) first identified this sedimentary pattern in New England salt marshes, attributing overwash sand and clay layers to known historic hurricanes. Donnelly et al. (2001) expanded this analysis to the paleorecord in a salt marsh in southern Rhode Island. At this salt marsh, aerial photos after major hurricanes in 1938 and 1954 confirm overwash fans. These overwash fans, along with four others, were documented in a series of 14 sediment cores, suggesting that several intense hurricanes had impacted the area since $\sim 1350 \mathrm{CE}$. Boldt et al. (2010) identified 30 distinct event beds spanning 2000 years in a series of eight sediment cores collected from a salt marsh in Mattapoisett, Massachusetts. Of the 30 distinct event beds, seven were attributed to historic severe landfalling hurricanes-1991 (Bob), 1960 (Donna), 1954 (Edna and Carol), 1944/1938, 1815, 1727, and 1638/1635. Boldt et al. (2010) inferred that the remaining 23 event beds, which predate European settlement in the region, were likely also deposited by similar hurricane strikes. Other studies have also identified sequences in the geologic record as due to intense storms, including deposits in Florida (Davis, Knowles, and Bland, 1989) and Alabama (Liu and Fearn, 1993), as well as in southern New England (Boothroyd, Friedrich, and McGinn, 1985; Emery, 1969).

Storm deposits from tropical cyclones often exhibit landwardfining trends (Brandon et al., 2014; Wallace and Anderson, 2010; Woodruff et al., 2008). These trends have been explained by the increasing time required for decreasing grain sizes to settle out of suspension while being advected landward during flooding (Woodruff et al., 2008). This advective-settling process has been explored in the paleorecord, especially in regard to constraining relative flooding and past magnitudes of both hurricanes (Brandon et al., 2014; Brandon et al., 2013; Bregy et al., 2018; Hong et al., 2018; Wallace and Anderson, 2010) and tsunamis (Baranes et al., 2016; Moore, McAdoo, and Ruffman, 2007). Preliminary research, however, has emphasized the importance of documenting lateral sorting trends across events to determine the deposition mechanisms at the site. This is necessary to adequately determine whether the deposit is suitable for use in the reconstruction of storm intensity. Here, the Boldt et al. (2010) study in Mattapoisett Marsh is expanded through examining grain size distributions of 22 event beds identified across three cores to examine lateral sorting patterns and to compare and contrast event beds to one another in an effort to better understand the nature of event bed deposition at the site.

\section{METHODS}

Mattapoisett Marsh $\left(41^{\circ} 39^{\prime} 8^{\prime \prime} \mathrm{N}, 70^{\circ} 47^{\prime} 12^{\prime \prime} \mathrm{W}\right)$ is an 8-acre marsh system located on Buzzards Bay between New Bedford, Massachusetts, and Wareham, Massachusetts (Figure 1). The marsh is separated from western Buzzards Bay by a $\sim 50-\mathrm{m}$ wide sand/gravel/cobble barrier. LIDAR surveys indicate that the modern topography of the barrier varies from $1-2.5 \mathrm{~m}$ (elevation based on the NAVD88 vertical datum). Two tidal creeks bisect the marsh from east to west and north to south before joining at an inlet at the western edge of the barrier. The inlet width is approximately $5 \mathrm{~m}$, and the creek spans $5-10 \mathrm{~m}$ in width and more than $350 \mathrm{~m}$ in length. The location of the barrier and the inlet have remained stable throughout the past century, with U.S. Geological Survey (USGS) topographic maps showing no changes in position of either in the past 130 years (Boldt et al., 2010). Simulations of waves and storm surge 


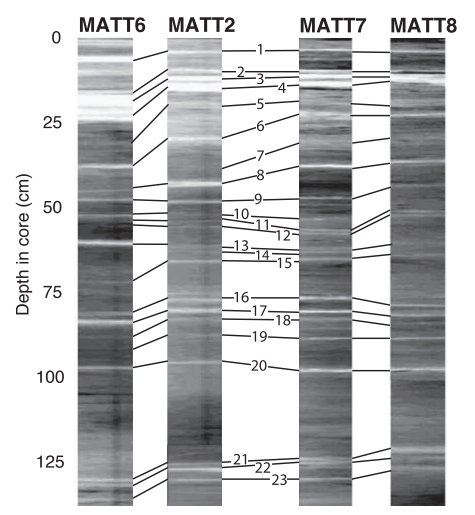

Figure 2. Radiographic images of the cores and event beds analyzed in this study, with inferred correlation lines connecting storm event beds. Lighter layers indicate areas of increased density; a potential storm event layer.

associated with Hurricane Bob in 1991 provide insight into how Mattapoisett Marsh is vulnerable during hurricane strikes to the west of the site. Although substantial sheltering and dispersion of wave energy that resulted in reduced wave height along the coast occurred, a focusing effect on the storm surge associated with the hurricane also occurred (Cheung et al., 2007). This enhancement of storm surge attributable to the SW orientation and conical shape of Buzzards Bay leaves Mattapoisett Marsh particularly vulnerable to coastal flooding during hurricanes making landfall to the west of the bay (Boldt et al., 2010; Redfield and Miller, 1957).

A series of eight vibracores were collected in 2007. The eight cores represent two transects: one beach parallel and one beach perpendicular. The cores (Matt1-Matt8) are primarily comprised of organic-rich high-marsh peat, punctuated by coarsergrained, denser sand layers (Boldt et al., 2010). Variation in the respective depths of strata between cores can in part be explained by local changes in the microtopography of the marsh surface (the potential for up to $15 \mathrm{~cm}$ of variation in any location at any moment in time can occur), as well as differences in compaction during collection of individual cores (between 5-20 cm).

For each core, sand layers were identified using highresolution $(200 \mu \mathrm{m})$ digital radiographs, where a sharp contrast in sediment density indicated the presence of a sand layer (Boldt et al., 2010). Previous research focused extensively on grain-size analysis of Matt2, a core in the beach-perpendicular transect, taken $83 \mathrm{~m}$ from the beach. Boldt et al. (2010) described event layers from Matt2 and traced them across several cores through particle-size analysis, x-ray fluorescence elemental analysis (Figure S1) and visual interpretation of radiographs (Figure 2). Following the inferred correlation previously published by Boldt et al. (2010), 22 correlative events from Matt7 were identified in Matt6 and Matt8 (Figure 2). The chronology of these events was constrained in Matt2 and then inferred across cores using a variety of techniques, including C-14 dating and gamma decay analysis of the cesium137 isotope. Here, an updated age model is developed along with associated $95 \%$ uncertainties using these dates and their

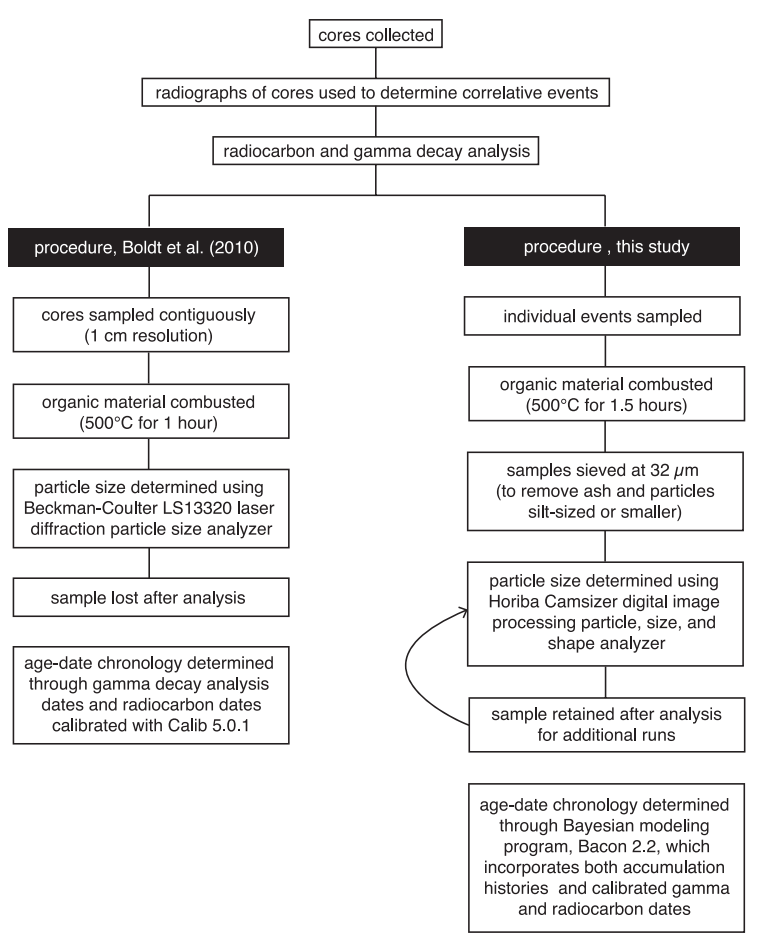

Figure 3. Flow chart of the differences in methodology used in this study and those used by Boldt et al. (2010).

uncertainties by employing a Bayesian age-depth modeling program (Bacon; Blaauw and Christen, 2011).

Boldt et al. (2010) analyzed the grain-size distribution of events in Matt2 by contiguously sampling the sediment core, combusting the organic material at $550^{\circ} \mathrm{C}$ for 1 hour, and running the resultant ash through a Beckman-Coulter LS13320 laser diffraction particle-size analyzer. As a result, the particle-size analysis included ash from combusted peat and siliciclastic sand grains, which influenced the distribution, making this kind of analysis inappropriate for accurately characterizing the transport of sand grains from storm events.

In the current work, a new approach was used to determine the grain-size distribution of other cores in the beachperpendicular transect. Differences between this study's approach and that of Boldt et al. (2010) are shown in Figure 3. Using the event correlations established by Boldt et al. (2010), identified storm events were resampled in three vibracores: Matt6, Matt7, and Matt8 (50 m, 100 m, and 115 $\mathrm{m}$ from shore, respectively). The samples were combusted at $550^{\circ} \mathrm{C}$ for 1.5 hours to remove organic material and then sieved at $32 \mu \mathrm{m}$ to isolate grains coarse silt-sized and larger. The coarse fraction of each sample was then determined by comparing the sieved weight of the sample to its original dry weight. This represents a departure from the 2010 procedure, where the samples were not sieved prior to grain size analysis: The sieving removes the fine-grained ash, and analyses on the remaining coarser grained fraction provided a more robust quantification of grain size for sands within event beds. Sieved samples were analyzed using a Horiba Camsizer digital image 

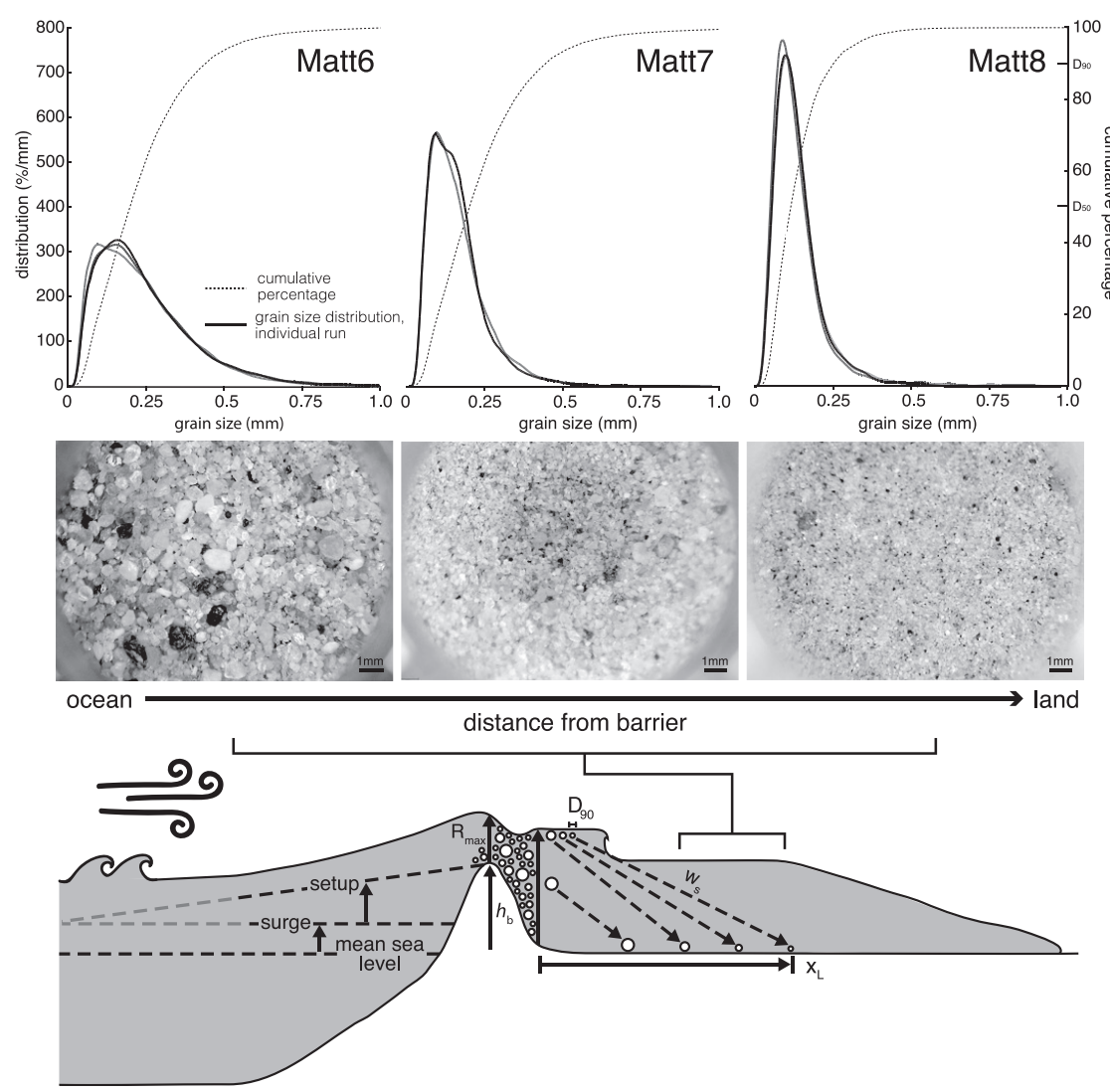

Figure 4. Grain-size distributions of each run (solid lines), cumulative percentages (dotted lines), and images (middle) of the sediment particles in the event beds for The Great Atlantic Hurricane, (1944, event 3) across the three study cores. Below: a diagram of the advective-settling model proposed by Woodruff et al. (2008).

processing particle, size, and shape analyzer at the University of Massachusetts, Amherst, capable of measuring particle diameters between $30 \mu \mathrm{m}$ and $3 \mathrm{~cm}$. Because a potential for variability in each run occurs, each sample was run three times and averaged (Figure 4). $D_{90}$, the size for which $90 \%$ of the particles in the size distribution are smaller, was used as a metric for the maximum grain size. Only events with a sufficient number of grains were analyzed for particle size. As discussed by Brandon et al. (2014), the unadjusted distribution (which does not consider the fine grains removed by the sieving process) is best suited for use in sediment transport calculations because the unadjusted $D_{90}$ value is more representative of the largest grains transported during a major flood event. Differences and similarities between means (both temporally, i.e. by event, and spatially, i.e. by core) were determined through one-way analysis of variance.

Per the Woodruff et al. (2008) advective-settling model, storm deposits from tropical cyclones should exhibit landward-fining trends, such that coarser grains are found deposited closer to the barrier and finer grains are found further from the barrier. As waves overwash the barrier during large-scale inundation events, observational and experimental data (Donnelly, Kraus, and Larson, 2006) suggest that flow behind the barrier becomes supercritical-the flow velocity is larger than the shallowwater wave velocity. During extreme inundation conditions, the sediment transport may also be dominated by suspended load (Donnelly, Kraus, and Larson, 2006). Given a sizable reduction in turbulence between the barrier and the area behind it, it is thought that settling of the sediment plays a larger role in the ultimate transport of the sediment grains than turbulent resuspension (Woodruff et al., 2008). Larger particles in a fluid settle out of suspension faster. Where the particles settle and how large they are can be related to maximum wave run-up over the barrier, which can in turn be related to storm intensity, per the advective-settling equation presented by Woodruff et al. (2008):

$$
R_{\max }=\left(\frac{x_{L}^{2} w_{s}^{2}}{g}\right)^{\frac{1}{3}}+h_{b} \#
$$

where $R_{\max }$ is the maximum wave-induced run-up over the barrier, $x_{L}$ is the distance of the particle from the barrier, $w_{s}$ is the particle fall velocity based on diameter (Ferguson and Church, 2004), $g$ is gravity, and $h_{b}$ is the height of the barrier (Figure 4). Thus, the maximum grain sizes in each event along the transect were analyzed to determine whether they followed a landward-fining trend, i.e. were deposited directly out of suspension and not greatly influenced by other processes, including subsequent erosion and remobilization. To accomplish this, a simple linear regression analysis was performed 

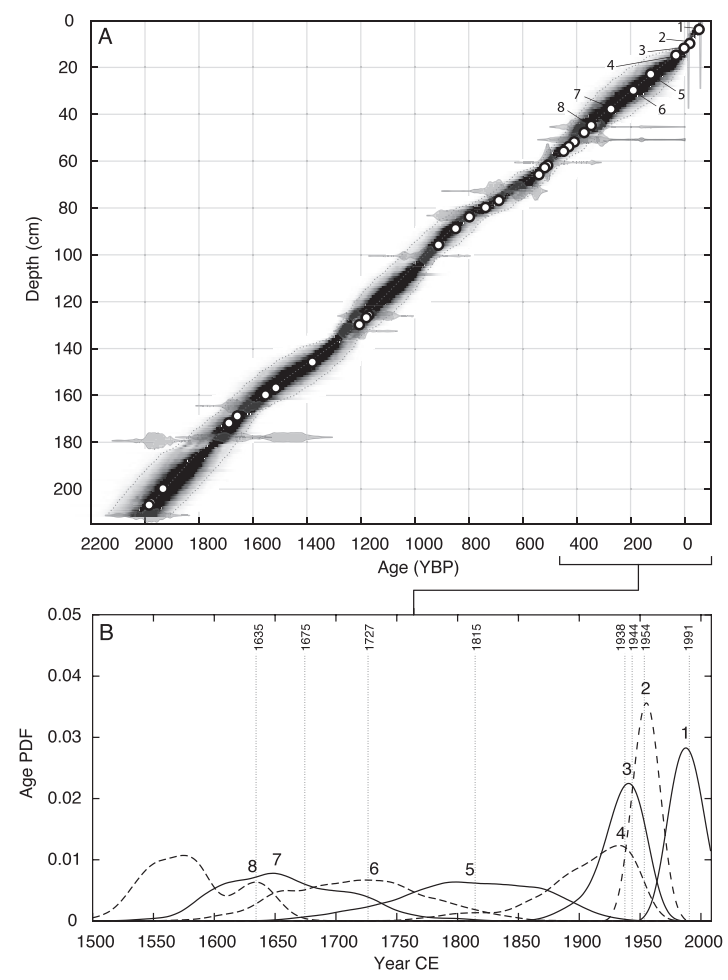

Figure 5. (A) Age estimates and 95\% confidence intervals of the different event beds identified in Matt2 (Figure 2) by depth. Age estimates are determined using Bayesian age-depth modeling program Bacon. The first seven events are identified and correlated with historic storms. C-14, cesium137, and surface dates used to create the age model are also indicated. (B) Probability density functions (PDFs) of the historic events (1-8, 1635 CE to present), used to determine correlative storm events. Vertical dotted lines indicate known storm events.

for each event-a negative correlation among points indicated that the results followed the expected landward-fining trend.

\section{RESULTS}

This study analyzed several different components of the event deposits to gain insights into the dynamics and trends of sedimentation in the system.

\section{Updated Event Attribution}

Boldt et al. (2010) used C-14 ages calibrated using Calib 5.0.1 (Reimer et al., 2009) to determine the ages of overwash deposits from our study site. Here, a more accurate chronology is developed through employing a Bayesian age-depth modeling program (Bacon 2.2; Blaauw and Christen, 2011), which considers accumulation histories for deposits. This updated chronology more accurately attributes storm events with tighter 95\% confidence intervals. Whereas Boldt et al. (2010) attributed the first/upper seven deposits to known historic storms (1991, 1960, 1954, 1944/1938, 1815, 1727, and 1635/ 1638), this chronology adjusts and refines that attribution (Figure 5).

The study used refined chronology and new simulation results from the Sea, Lake, and Overland Surges from Hurricanes model (SLOSH; Jelesnianski, Chen, and Shaffer, 1992) to determine storm surge heights at the Mattapoisett. If a storm was modeled to produce a surge $>1 \mathrm{~m}$ - the minimum height of the current sandy barrier-then it was considered to have the potential to produce a deposit. Using this metric and the probability distribution functions generated with the refined chronology, the first eight events are attributed to historic hurricanes, beginning with the Great Colonial Hurricane of 1635 and ending with the last documented flood event at the site (Hurricane Bob in 1991) prior to core collection (Figure 5, Table 1).

\section{Grain-Size Analysis}

The grain-size range analyzed extended from the minimum sieve size of $32 \mu \mathrm{m}$ up to the largest observed particle size of 3 $\mathrm{mm})$. Values for $D_{50}$, the median grain size, and $D_{90}$ were not adjusted for the removal of any fine-grained ash that exceeded $32 \mu \mathrm{m}$ (Figure 6). The $D_{90}$ values for Matt6, the core closest to the barrier, averaged $450 \mu \mathrm{m}$, with a range from $175 \mu \mathrm{m}$ to 699 $\mu \mathrm{m}$ for the 14 event samples (Figure $6 \mathrm{~A}$ ). The $D_{90}$ values for Matt7 averaged $580 \mu \mathrm{m}$, with a range from $193 \mu \mathrm{m}$ to $1601 \mu \mathrm{m}$ for the 30 event samples (Figure $6 \mathrm{~B}$ ). The $D_{90}$ values for Matt8, the core farthest from the barrier, averaged $514 \mu \mathrm{m}$, with a range from $194 \mu \mathrm{m}$ to $832 \mu \mathrm{m}$ for the 20 event samples (Figure $6 \mathrm{C})$. The variability in $D_{90}$ among different runs of the same sample was also considered. Matt6 had the least variability between individual runs (average standard deviation [SD] 140 $\mu \mathrm{m}$, likely attributable to a larger sample size), whereas Matt7 had the most (average SD $338 \mu \mathrm{m}$ ).

\section{Spatial Trends in Deposition}

Although no significant difference occurred in the mean $D_{90}$ value across each core, the mean $D_{50}$ value for Matt6 was significantly higher than that of Matt7 and Matt8 $(p<0.001$; Table 2). The $D_{90}$ values are expected to decrease as distance from the barrier increases; however, not all study events followed this trend within uncertainty (defined as $1 \mathrm{SD}$ about

Table 1. Updated event chronology for Matt2, taking into consideration PDFs generated from Bacon Bayesian age-depth modeling and SLOSH model results.

\begin{tabular}{cccccc}
\hline \hline $\begin{array}{c}\text { Event } \\
\text { (This Study) }\end{array}$ & $\begin{array}{c}\text { Storm (year) } \\
\text { (This Study) }\end{array}$ & $\begin{array}{c}\text { Event } \\
\text { (Boldt et al., 2010) }\end{array}$ & $\begin{array}{c}\text { Storm (year) } \\
\text { (Boldt et al., 2010) }\end{array}$ & $\begin{array}{c}\text { Maximum } \\
\text { Surge (m) }\end{array}$ & $\begin{array}{c}\text { Maximum } \\
\text { Windspeed (m/s) }\end{array}$ \\
\hline 1 & 1991 & 1 & 1991 & 2.68 & 48.11 \\
2 & 1954 & 2 & 1960 & 2.16 & 34.24 \\
3 & 1944 & 3 & 1954 & 1.68 & 37.94 \\
4 & 1938 & 4 & $1944 / 1938$ & 3.26 & 36.51 \\
5 & 1815 & not identified & not attributed & 3.47 & 40.99 \\
6 & 1727 & 5 & 1815 & 2.16 & 39.54 \\
7 & 1675 & 6 & 1727 & 1.34 & 33.63 \\
8 & 1635 & 7 & $1635 / 1638$ & 4.45 & 57.49 \\
\hline
\end{tabular}



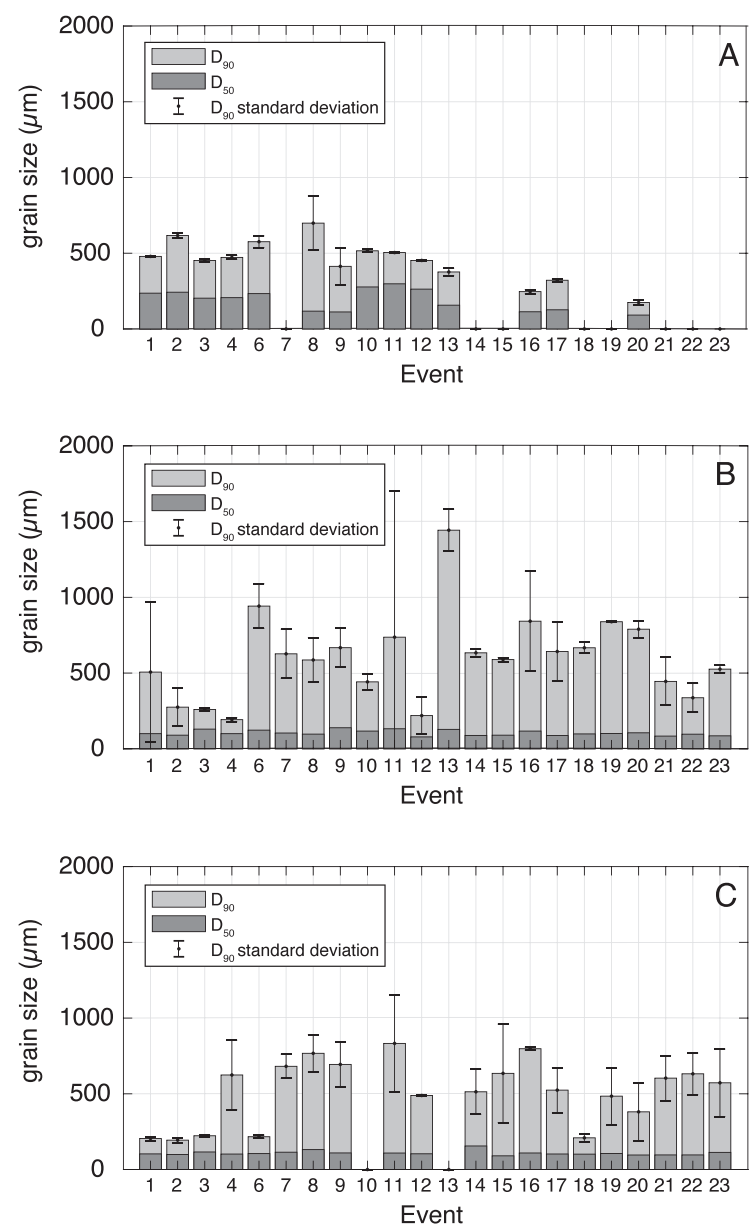

Figure 6. The $D_{50}$ and $D_{90}$ values and associated $D_{90}$ standard deviation for (A) Matt6, (B) Matt7, (C) Matt8.

the regression; Figure 7). Of the 22 storm event deposits that were identified in at least two of the three transect cores, eight events $(36.4 \%)$ followed a landward-fining trend, eight events (36.4\%) followed a landward-coarsening trend, and six events (27.2\%) did not follow either trend within uncertainty (Figure 7). Coefficients of the regression lines can be found in the supplemental material.

\section{Temporal Trends in Deposition}

To understand how historic events compared to prehistoric events, the two groups were analyzed. The mean maximum grain size of the historic events (events 1-8) is significantly higher $(p<0.01)$ than the mean maximum grain size of the prehistoric events (events 9-22). This trend is observed when averaging events across all three cores in the transect. Individual cores show no statistically significant difference in mean maximum grain size between the two temporal frames of reference.

\section{Spatiotemporal Trends in Deposition}

Spatial trends in grain size were also analyzed temporally (Figure 7). Of the 11 events with data from all three cores, a
Table 2. Average and standard deviation of maximum grain size (as described by $\left.\mathrm{D}_{90}\right)$ and median grain size $\left(\mathrm{D}_{50}\right)$ for event deposits in primary cores shown in Figure 1.

\begin{tabular}{lcrr}
\hline \hline & Matt6 & Matt7 & Matt8 \\
\hline$D_{90}(\mu \mathrm{m})$ & 450 & 580 & 514 \\
Standard deviation $(\mu \mathrm{m})$ & 140 & 338 & 211 \\
$D 50(\mu \mathrm{m})$ & 191 & 98 & 108 \\
Standard deviation $(\mu \mathrm{m})$ & 70 & 20 & 14 \\
\hline
\end{tabular}

statistically significant difference $(p<0.05)$ occurs between historic and prehistoric events. Historic events (1-6) follow a landward-fining trend, whereas prehistoric events $(9,11,16$, 17, 20) follow a landward-coarsening trend. Event 8, which corresponds to the 1635 hurricane, does not follow either trend within uncertainty, suggesting a temporal transition.

\section{DISCUSSION}

This work represents a reexamination of event beds documented by Boldt et al. (2010), using new techniques to (1) obtain more accurate measurements of maximum grain size of event beds, and (2) apply more advanced age modeling techniques to improve attribution of historic event beds to known storms.

As discussed in Boldt et al. (2010), beds of coarser-grained sediment are likely sourced from hurricane events for several reasons. The ages of the event beds match well with known historic hurricane events. This makes sense because of the coastal geometry of the system. The marsh is small, of low relief, and adjacent to a sandy barrier, thus conducive to overwash deposits from storm surge events. The marsh is protected from $\mathrm{NE}$ winds, making overwash events from nor'easters less likely. The geometry of Buzzards Bay accentuates storm surge for hurricanes, making landfall to the west (Cheung et al., 2007). All of the attributed hurricanes made landfall to the west of Mattapoisett marsh, as such they were likely to produce an overwash event at the site. It is also important to consider that no false positives occurred within the historic record, i.e. there are no event beds that cannot be reasonably attributed to a hurricane event. Tsunamis are capable of producing coastal inundation and overwash-induced deposits; however, they are extremely rare along the eastern coast of the United States, lacking any significant historic accounts in the region over the last 400 years, and certainly cannot be the mechanism for a vast majority, if not all of the event beds over the last 2000 years.

Previous research into tropical cyclone event deposits has identified a fining-landward trend, consistent with an inundation/run-up overwash regime (Brandon et al., 2014; Donnelly, Kraus, and Larson, 2006; Woodruff et al., 2008). The fall velocity of a given grain determines the sorting trends seen in deposition. Fall velocity is dependent on several factors. Stokes' Law applies to small particles, where the settling is impeded by the drag associated with the laminar flow surrounding the grain (Ferguson and Church, 2004). Settling of small particles is slow, and fall velocity increases with the square of the diameter of the particle. Larger particles settle far more rapidly because their settling is impeded by the drag associated with the wake behind each particle. As such, their fall velocity increases with the square root of the diameter (Ferguson and 


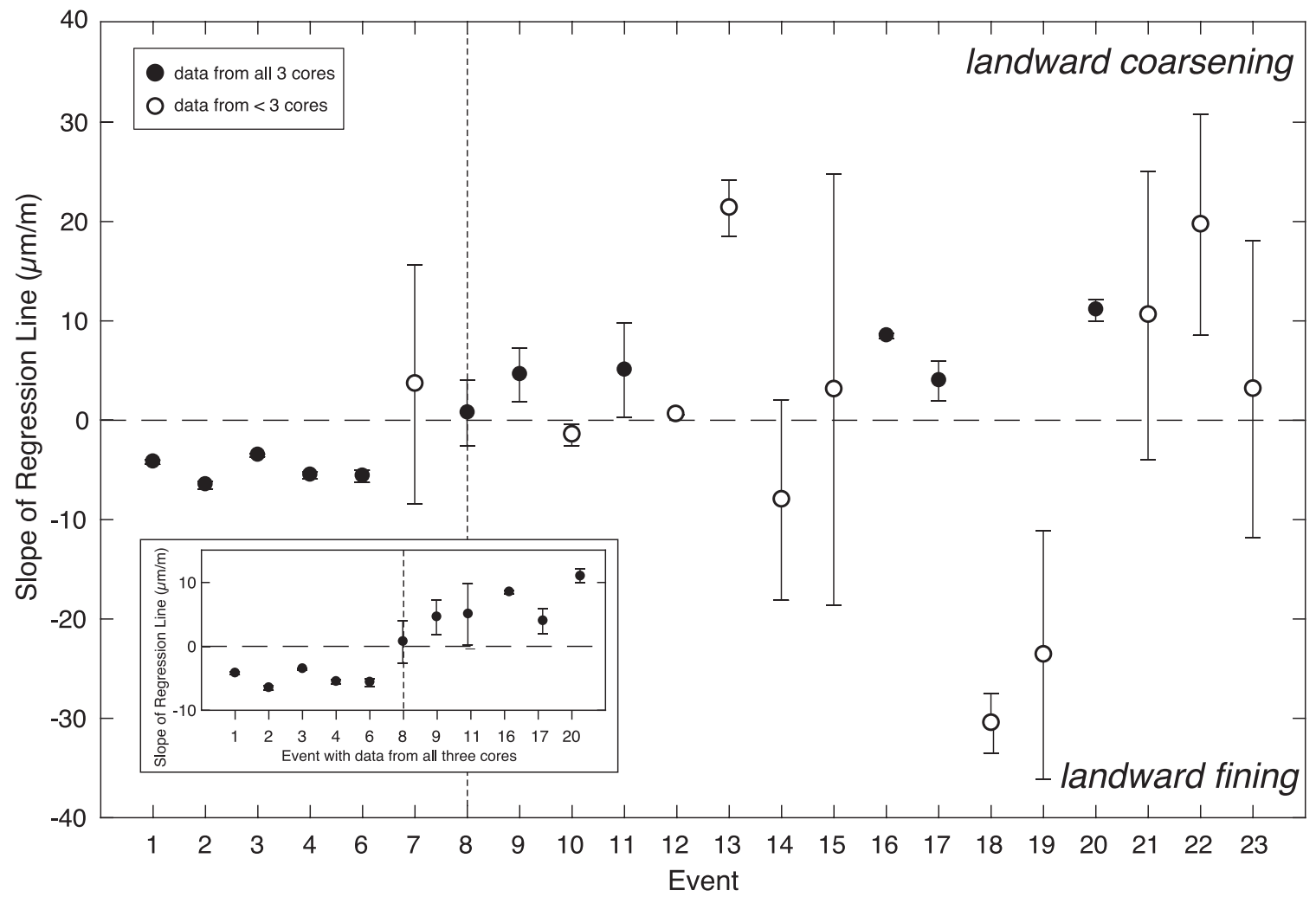

Figure 7. Plot of the slope of the regression line of $D_{90}$ values for individual events across the transect of cores. A negative slope indicates a landward-fining trend, whereas a positive slope indicates a landward-coarsening trend. Filled points have a regression with all three cores in the transect. Empty points have data from $<3$ cores. The boundary between historic and prehistoric values is indicated by a dashed vertical line. Inset: the filled points, historic values (events $1-4,6,8)$ are statistically different $(p<0.05)$ from prehistoric values (events $9,11,16,17,20)$.

Church, 2004). In both cases, larger particles have larger fall velocities and settle sooner, resulting in a landward-fining overwash deposit. This trend, however, is present in only $36.4 \%$ of the 22 events identified, suggesting a more complicated sediment transport and deposition relationship.

A landward-fining model assumes that sediment is sourced primarily from the sandy barrier and deposited directly onto the marsh surface. In reality, several potential factors influence the perceived settling trends (Figure 8). Salt marsh vegetation has well-documented abilities to trap sediment (Fagherazzi et al., 2012; Gleason et al., 1979), which may enhance lateral sorting such that much of the deposition occurs close to the barrier. The ability of marsh plants to trap sediment is dependent on a variety of factors-including plant distribution, stem density, and stem height relative to wave height and water depth-thus when these factors are dominant, a transport model that does not consider them will not accurately predict sediment settling trends on a marsh platform. Turbulent mixing/resuspension and erosion of recently deposited or previously trapped sediment may further influence settling trends (Booth et al., 2000). A storm may also deposit sediment through aeolian processes (Rodriguez et al., 2013), which would also change the signature of the storm, though the grain size of the deposits at Mattapoisett are likely too coarse to be exclusively sourced from aeolian processes.
Sediment may also be sourced from channel banks, as opposed to the sandy barrier to the south. The geomorphology of the marsh suggests that the furthest cores in the study transect, bordered on the south and west by an established tidal channel, may be more influenced by sediment deposition from overtopping of the creek-channel banks than deposition from barrierbeach overwash.

Another proposed source of sediment is from ice rafting during particularly cold winters. Argow, Hughes, and FitzGerald (2011) determined that ice rafts have the potential to transport sediment loads more than $100 \mathrm{~m}$ from the source and that $97 \%$ of ice rafts carry sizeable sediment loads. Whereas ice rafts presently tend to form further north in New England (FitzGerald et al., 2020; Hardwick-Witman, 1986; Wood, Kelley, and Belknap, 1989), it is possible that cooler climates may have extended their range in the past. It is important to consider, however, that ice rafting is often patchy and is not wholly likely to contribute to traceable, widespread layers of sediment across $>100 \mathrm{~m}$ of marsh. For example, while an intense extratropical cyclone in 2018 led to the ice-rafting of $18,000 \mathrm{~m}^{3}$ of sediment across the Great Marsh in northern Massachusetts, deposits-while spread throughout the marsh-were relatively patchy, particularly deposits of substantial thickness (FitzGerald et al., 2020). 


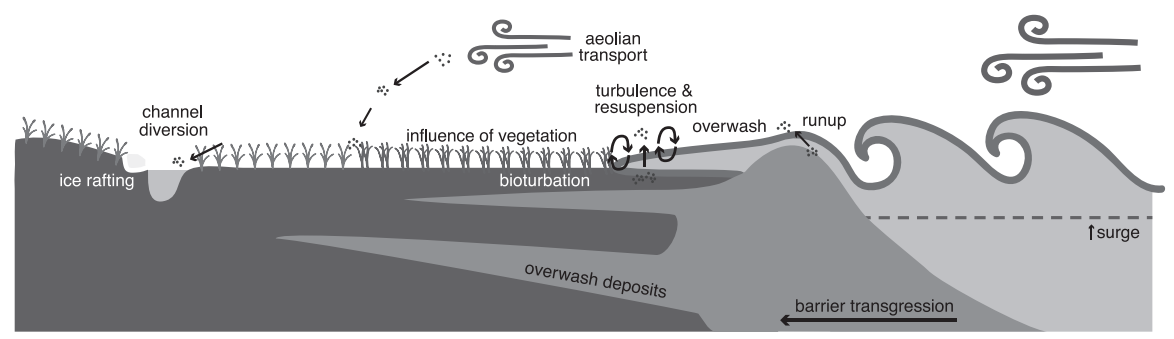

Figure 8. Additional potential sources of sediment to the system.

Complete inundation of the barrier during intense, surgedominated storms also influences sediment transport dynamics. Modeling of the effects of Hurricane Bob (1991) on southern New England suggests that Mattapoisett, along with other areas in Buzzards Bay, may have experienced an inundation regime during the event (Cheung et al., 2007), where the storm surge alone is greater than the height of the barrier (Donnelly, Kraus, and Larson, 2006). The SLOSH (Jelesnianski, Chen, and Shaffer, 1992) modeled storm-surge estimates for Mattapoisett during Hurricane Bob exceeded $2.5 \mathrm{~m}$, which is above the LIDAR-recorded barrier height of 1-2.5 m (Table 1). The SLOSH model results for the Great New England Hurricane of 1938 and the Great Colonial Hurricane of 1635 also indicate surges of $>3 \mathrm{~m}$ and $>4 \mathrm{~m}$, respectively (Table 1). Extreme inundation effectively negates the influence of the barrier because water and sediment can flow unimpeded over the barrier, depositing sediment only as the sheet flow slows (Donnelly, Kraus, and Larson, 2006). As such, it is important to consider that in these cases, the time of greatest sediment transport may not be at the point of maximum inundation.

Of particular interest is the difference between historic and prehistoric deposits. The first seven events identified in the study sediment cores are correlated to hurricanes dating from the Great Colonial Hurricane of 1635 to present. Of those events, all five events with data from all three cores follow a landward-fining trend, where, at the very least, the maximum grain size of the event bed closest to the barrier is larger than the maximum grain size of the event bed furthest from the barrier. The mean maximum grain size of the historic events is also significantly higher than the mean maximum grain size of the prehistoric events. The prehistoric events, however, in general display a landward-coarsening trend, which is seemingly at odds with processes proposed by the advective-settling model.

The simplest way to explain an increase in grain size toward present, particularly for the core closest to the barrier (Matt6; Figure 4A), is a migration of the barrier separating the marsh from the ocean. Landward migration of a barrier beach is most often linked to sea-level rise. A sea-level reconstruction from Barn Island, Connecticut, indicates a linear increase in mean sea level of approximately $1.0 \pm 0.2 \mathrm{~mm} / \mathrm{yr}$ from $\sim 1300 \mathrm{CE}$ to $\sim 1850 \mathrm{CE}$, with that rate increasing almost threefold in the mid-19 ${ }^{\text {th }}$ century (Donnelly et al., 2004). Tide gauge data from Woods Hole, Massachusetts (NOAA tide gauge 8447930), indicates an increase in sea level of approximately $2.81 \pm$
$0.18 \mathrm{~mm} / \mathrm{yr}$ over the past 83 years, with similar temporal patterns in accelerated sea-level rise in New York and Boston (Talke, Kemp, and Woodruff, 2018). As sea level rises, barriers tend to migrate landward, with research indicating that barriers less than $200 \mathrm{~m}$ in width migrate landward primarily through overwash (Bruun, 1988; Hennessy and Zarillo, 1987; Leatherman, 1983; Lorenzo-Trueba and Ashton, 2014). Barrier migration is controlled largely by two primary factors: sea-level change and sediment budget (Curray, 1964), though more recent studies have expanded on this list of governing factors (McBride et al., 2013). Overwash in particular contributes to migration by removing sediment at the front of the barrier and depositing it landward (Donnelly, Kraus, and Larson, 2006). Given the record of at least 30 overwash-deposited event beds over the past 2000 years, it is highly probable that these events-often several within the same century-played a role in barrier migration.

Though analysis of USGS topographic maps indicated no change in the location of the barrier at Mattapoisett for the last 125 years (Boldt et al., 2010), additional state assessments indicate that shoreline retreat rates in front of Mattapoisett Marsh average $0.06 \mathrm{~m} / \mathrm{yr}$ (ranging from $0.04-0.15 \mathrm{~m} / \mathrm{yr}$; Thieler et al., 2013). The barrier may have moved landward; however, the position of the cores, taken in 2007, remains static. This suggests that deeper events may actually have been deposited further from the barrier than present. The mean maximum grain size for the historic events is significantly higher than the mean maximum grain size for the prehistoric events, further bolstering this hypothesis.

The transition from landward-coarsening to landward-fining deposition occurs by $1679 \mathrm{CE}$, when the town of Rochester, which originally included the town of Mattapoisett, was settled. This suggests that anthropogenic changes in sediment supply and coastal stabilization may be influential. The transition also occurs not long after the Great Colonial Hurricane of 1635, which devastated SE New England with category 3 winds (Jarvinen, 2006) and modeled surge at Mattapoisett of $>4.5 \mathrm{~m}$. It is possible that surge and winds associated with this massive storm substantially changed the geomorphic layout of the area. For example, a shift in the course of the creek system could result in greater sediment supply and transport from that source prior to 1635, particularly if, as estimated, the barrier was several meters further oceanward than present. These shifts would preferentially influence deposition within study cores closest to the creek. 
The changes in settling trends could be representative of shifts in the relative contributions of several sediment sources, particularly for the cores further from the barrier. The advective-settling model assumes that the vast majority of sediment is sourced directly from the sandy barrier, but shifts in event magnitude and storm direction attributable to largerscale climatic or geomorphologic changes may also play a role in the observed deposition patterns. For example, a shift in the direction of approach, i.e. waves approaching from the west as opposed to the south, would emphasize potential channel diversion by the main tidal inlet. The lack of a sandy barrier on the western side of the marsh would reduce the surge necessary for overwash and subsequent deposition, resulting in largerdiameter grains deposited at the core locations closer to the western border of the marsh.

Ultimately, this study has implications for future attempts to use the advective-settling model by Woodruff et al. (2008) to inversely model storm intensity metrics from grain-size distributions. Whereas the model may accurately predict the intensity of storms in a simple system where the majority of sediment is sourced directly from an adjacent barrier, systems with more complex geomorphology and resultant flood processes are less suited for its application. The settling trends and larger spatiotemporal dynamics of most systems are often subtle until explored in greater depth. A site-wide approach to sampling, along with potential coupling with high-resolution, three-dimensional wave modeling, is necessary to adequately capture the dynamics of these systems. It is recommended that several sediment cores be evenly spaced in a grid pattern throughout the study area, spatially encompassing the area of interest. Distribution of sediment cores will vary by the total study area based on areas of interest and to maximize returns (e.g., in a marsh the size of Mattapoisett, a core every 10-20 m would likely be sufficient to effectively capture spatial variation in sedimentation, but areas of particular interest, such as the tidal channel and its influence on sediment source, would be sampled more extensively). Though this study is limited by preexisting sediment cores, an even more expansive approach in sampling - unlike the traditional transect-based approach to paleo-hurricane research-would provide an even clearer picture of depositional patterns and predominant associated flood mechanisms.

\section{CONGLUSIONS}

Mattapoisett Marsh presents a unique environment to study grain-size trends in hurricane-induced storm deposits. Previous reconstructions of storm frequency have assumed relatively straightforward overwash and deposition dynamics, but a deeper look into the intricacies of spatial and temporal grainsize trends requires a more nuanced approach. Whereas many reconstructions focus on one core from one location, a wholesite analysis is necessary to properly constrain the sediment dynamics of past flood events. The strong incongruity between historic and prehistoric deposits may be unique to Mattapoisett Marsh, but the breadth of variation in grain-size trends likely apply to back-barrier marshes throughout New England. Backbarrier marshes provide a valuable location for preserving storm-induced overwash events, but the complexity of deposition dynamics must be considered in future reconstructions.

\section{LITERATURE CITED}

Argow, B.A.; Hughes, Z.J., and FitzGerald, D.M., 2011. Ice raft formation, dispersion and sedimentation on New England salt marshes. Continental Shelf Research, 31, 1294-1305. doi:10.1061/ 40926(239)61

Baranes, H.E.; Woodruff, J.D.; Wallace, D.J.; Kanamaru, K., and Cook, T.L., 2016. Sedimentological records of the C.E. 1707 Hōei Nankai Trough tsunami in the Bungo Channel, southwestern Japan. Natural Hazards, 84, 1185-1205. doi:10.1007/s11069-0162498-3

Blaauw, M. and Christen, J.A., 2011. Flexible paleoclimate age-depth models using an autoregressive gamma process. Bayesian Analysis, 6(3), 457-474. doi:10.1214/11-BA618

Boldt, K.V.; Lane, P.; Woodruff, J.D., and Donnelly, J.P., 2010. Calibrating a sedimentary record of overwash from Southeastern New England using modeled historic hurricane surges. Marine Geology, 275(1-4), 127-139. doi:10.1016/j.margeo.2010.05.002

Boose, E.R.; Chamberlin, K.E., and Foster, D.R., 2001. Landscape and regional impacts of hurricanes in New England. Ecological Monographs, 71(1), 27-48.

Booth, J.G.; Miller, R.L.; McKee, B.A., and Leathers, R.A., 2000. Wind-induced bottom sediment resuspension in a microtidal estuary. Continental Shelf Research, 20(7), 785-806.

Boothroyd, J.C.; Friedrich, N.E., and McGinn, S.R., 1985. Geology of microtidal coastal lagoons: Rhode Island. Marine Geology, 63(1-4), 35-76. doi:10.1016/0025-3227(85)90079-9

Brandon, C.M.; Woodruff, J.D.; Donnelly, J.P., and Sullivan, R.M., 2014. How unique was Hurricane Sandy? Sedimentary reconstructions of extreme flooding from New York Harbor. Scientific Reports, 4(7366), 1-9. doi:10.1038/srep07366

Brandon, C.M.; Woodruff, J.D.; Lane, D.P., and Donnelly, J.P., 2013. Tropical cyclone wind speed constraints from resultant storm surge deposition: A 2500 year reconstruction of hurricane activity from St. Marks, FL. Geochemistry, Geophysics, Geosystems, 14(8), 29933008. doi:10.1002/ggge.20217

Bregy, J.C.; Wallace, D.J.; Minzoni, R.T., and Cruz, V.J., 2018. 2500year paleotempestological record of intense storms for the northern Gulf of Mexico, United States. Marine Geology, 396, 26-42. doi:10. 1016/j.margeo.2017.09.009

Bruun, P., 1988. The Bruun rule of erosion by sea-level rise: A discussion on large-scale two- and three-dimensional usages. Journal of Coastal Research, 4(4), 627-648. doi:10.2307/4297466

Cheung, K.F.; Tang, L.; Donnelly, J.P.; Scileppi, E.M.; Liu, K.-B.; Mao, X.-Z.; Houston, S.H., and Murnane, R.J., 2007. Numerical modeling and field evidence of coastal overwash in southern New England from Hurricane Bob and implications for paleotempestology. Journal of Geophysical Research: Earth Surface, 112(F3), 124. doi:10.1029/2006JF000612

Curray, J.R., 1964. Transgressions and regressions. In: Miller, R.L. (ed.), Papers in Marine Geology. New York: MacMillan, pp. 175203.

Davis, R.A.; Knowles, S.C., and Bland, M.J., 1989. Role of hurricanes in the Holocene stratigraphy of estuaries; examples from the Gulf Coast of Florida. Journal of Sedimentary Research, 59(6), 10521061. doi:10.1306/212F90ED-2B24-11D7-8648000102C1865D

Donnelly, C.; Kraus, N., and Larson, M., 2006. State of knowledge on measurement and modeling of coastal overwash. Journal of Coastal Research, 22(4), 965-991. doi:10.2112/04-0431.1

Donnelly, J.P.; Cleary, P.; Newby, P., and Ettinger, R., 2004. Coupling instrumental and geological records of sea-level change: Evidence from southern New England of an increase in the rate of sea-level rise in the late 19th century. Geophysical Research Letters, 31(5), 2-5. doi:10.1029/2003GL018933

Donnelly, J.P.; Hawkes, A.D.; Lane, P.; MacDonald, D.; Shuman, B.N.; Toomey, M.R.; van Hengstum, P.J., and Woodruff, J.D., 2015. Climate forcing of unprecedented intense-hurricane activity in the last 2000 years. Earth's Future, 3(2), 49-65. doi:10.1002/ 2014EF000274

Donnelly, J.P.; Smith Bryant, S.; Butler, J.; Dowling, J.; Fan, L.; Hausmann, N.; Newby, P.; Shuman, B.; Stern, J.; Westover, K. and Webb III, T., 2001. $700 \mathrm{yr}$ sedimentary record of intense 
hurricane landfalls in southern New England. Geological Society of America Bulletin, 113(6), 714-727. doi:10.1130/0016-7606(2001) $113<0714$ :YSROIH $>2.0 . \mathrm{CO} ; 2$

Emanuel, K., 2008. The hurricane-climate connection. Bulletin of the American Meteorological Society, 89, ES10-ES20.

Emery, K.O. 1969. A Coastal Pond Studied by Oceanographic Methods. Falmouth, Massachusetts: Oyster Pond Environmental Trust, $111 p$.

Fagherazzi, S.; Kirwan, M.L.; Mudd, S.M.; Guntenspergen, G.R.; Temmerman, S.; D’Alpaos, A.D.; van de Koppek, J.; Rybczyk, J.M.; Reyes, E.; Craft, C., and Clough, J., 2012. Numerical models of salt marsh evolution: Ecological, geormorphic, and climatic factors. Reviews of Geophysics, 50(1), 1-28. doi:10.1029/2011RG000359

Ferguson, R.I. and Church, M., 2004. A simple universal equation for grain settling velocity. Journal of Sedimentary Research, 74(6), 933-937. doi:10.1306/051204740933

FitzGerald, D.M.; Hughes, Z.J.; Georgiou, I.Y.; Black, S., and Novak, A., 2020. Enhanced, climate-driven sedimentation on salt marshes. Geophysical Research Letters, 47(10), 1-9. doi:10.1029/2019GL086737

Gleason, M.L.; Elmer, D.A.; Pien, N.C., and Fisher, J.S., 1979. Effects of stem density upon sediment retention by salt marsh cord grass, Spartina alterniflora loisel. Estuaries, 2, 271-273. doi:10.2307/ 1351574

Hardwick-Witman, M.N., 1986. Aerial survey of a salt marsh: Ice rafting to the lower intertidal zone. Estuarine, Coastal and Shelf Science, 22(3), 379-383. doi:10.1016/0272-7714(86)90050-8

Hennessy, J.T. and Zarillo, G.A., 1987. The interrelation and distinction between flood-tidal delta and washover deposits in a transgressive barrier island. Marine Geology, 78(1-2), 35-56. doi:10.1016/0025-3227(87)90067-3

Holland, G.J. and Webster, P.J., 2007. Heightened tropical cyclone activity in the North Atlantic: Natural variability or climate trend? Philosophical Transactions. Series A, Mathematical, Physical, and Engineering Sciences, 365(1860), 2695-2716. doi:10.1098/rsta. 2007.2083

Hong, I.; Pilarczyk, J.E.; Horton, B.P.; Fritz, H.M.; Kosciuch, T.J.; Wallace, D.J.; Dike, C.; Rarai, A.; Harrison, M.J., and Jockley, F.R., 2018. Sedimentological characteristics of the 2015 Tropical Cyclone Pam overwash sediments from Vanuatu, South Pacific. Marine Geology, 396, 205-214. doi:10.1016/j.margeo.2017.05.011

Jarvinen, B.R., 2006. Storm Tides in Twelve Tropical Cyclones (including Four Intense New England Hurricanes). Miami, Florida.

Jarvinen, B.R. and Caso, E.L., 1978. A Tropical Cyclone Data Tape for the North Atlantic Basin 1886-1977: Contents, Limitations, and Uses. Miami, Florida. NOAA Technical Memo, NWS NHC 6.

Jelesnianski, C.P.; Chen, J., and Shaffer, W.A., 1992. SLOSH: Sea, Lake, and Overland Surges from Hurricanes. Silver Spring, Maryland. NOAA Technical Report, NWS 48

Landsea, C.W. and Franklin, J.L., 2013. Atlantic hurricane database uncertainty and presentation of a new database format. Monthly Weather Review, 141(10), 3576-3592. doi:.1175/MWR-D-12-00254.1

Leatherman, S.P., 1983. Barrier dynamics and landward migration with Holocene sea-level rise. Nature, 301, 415-417. doi:10.1038/ $301415 \mathrm{a} 0$

Liu, K.-b. and Fearn, M.L., 1993. Lake-sediment record of late Holocene hurricane activities from coastal Alabama. Geology, 21(9), 793-796. doi:/10.1130/0091-7613(1993)021<0793:LSROLH> 2.3. $\mathrm{CO} ; 2$

Lorenzo-Trueba, J. and Ashton, A.D., 2014. Rollover, drowning, and discontinuous retreat: Distinct modes of barrier response to sealevel rise arising from a simple morphodynamic model. Journal of Geophysical Research: Earth Surface, 119(4), 779-801. doi:10.1002/ 2013JF002941
Ludlum, D.M., 1963. Early American Hurricanes. Boston: American Meterological Society, 198p.

McAdie, C.J.; Landsea, C.W.; Neumann, C.J.; David, J.E.; Blake, E.S., and Hammer, G.R., 2009. Tropical cyclones of the North Atlantic Ocean 1851-2006. Historical Climatology Series, 6-2, 1-239. https://www.nhc.noaa.gov/pdf/TC_Book_Atl_1851-2006_lowres.pdf

McBride, R.A.; Anderson, J.B.; Buynevich, I.V.; Cleary, W.; Fenster, M.S.; FitzGerald, D.M.; Harris, M.S.; Hein, C.J.; Klein, A.H.F.; Liu, B.; de Menezes, J.T.; Pejrup, M.; Riggs, S.R.; Short, A.D.; Stone, G.W.; Wallace, D.J., and Wang, P., 2013. Morphodynamics of barrier systems: A synthesis. Earth Systems and Environmental Sciences: Treatise on Geomorphology, 10, 166-244. doi:10.1016/ B978-0-12-374739-6.00279-7

Moore, A.L.; McAdoo, B.G., and Ruffman, A., 2007. Landward fining from multiple sources in a sand sheet deposited by the 1929 Grand Banks tsunami, Newfoundland. Sedimentary Geology, 200(3-4), 336-346. doi:10.1016/j.sedgeo.2007.01.012

Orson, R.A. and Howes, B.L., 1992. Salt marsh development studies at Waquoit Bay, Massachusetts: Influence of geomorphology on long-term plant community structure. Estuarine, Coastal and Shelf Science, 35(5), 453-471. doi:10.1016/S0272-7714(05)80025-3

Redfield, A.C. and Miller, A.R., 1957. Water levels accompanying Atlantic Coast hurricanes. Meteorology Monographs, 2, 1-22

Reimer, P.J.; Baillie, M.G.L.; Bard, E.; Bayliss, A.; Beck, J.W.; Blackwell, P.G.; Ramsey, C.B.; Buck, C.E.; Burr, G.S.; Edwards, R.L.; Friedrich, M.; Grootes, P.M.; Guilderson, T.P.; Hajdas, I.; Heaton, T.J.; Hogg, A.G.; Hughen, K.A.; Kaiser, K.F.; Kromer, B.; McCormac, F.G.; Manning, S.W.; Reimer, R.W.; Richards, D.A.; Southon, J.R.; Talamo, S.; Turney, C.S.M.; van der Plicht, J., and Weyhenmeyer, C.E., 2009. IntCal09 and Marine09 radiocarbon age calibration curves, 0-50,000 years cal BP. Radiocarbon, 51(4), 1111-1150. doi:10.1017/S0033822200034202

Rodriguez, A.B., Fegley, S.R., Ridge, J.T., VanDusen, B.M., and Anderson, N., 2013. Contribution of aeolian sand to backbarrier marsh sedimentation. Estuarine, Coastal and Shelf Science, 117, 248-259. https://doi.org/10.1016/j.ecss.2012.12.001

Sobel, A.H.; Camargo, S.J.; Hall, T.M.; Lee, C.-Y.; Tippett, M.K., and Wing, A., 2016. Human influence on tropical cyclone intensity. Science, 353(6296), 242-246.

Talke, S.A.; Kemp, A.C., and Woodruff, J., 2018. Relative sea level, tides, and extreme water levels in Boston Harbor from 1825 to 2018. Journal of Geophysical Research: Oceans, 123(6), 3895-3914. doi:10.1029/2017JC013645

Thieler, E.R.; Smith, T.L.; Knisel, J.M., and Sampson, D.W., 2013 Massachusetts Shoreline Change Mapping and Analysis Project, 2013 Update. Reston, Virginia: U.S. Geological Survey, 52p.

Wallace, D.J. and Anderson, J.B., 2010. Evidence of similar probablility of intense hurricane strikes for the gulf of Mexico over the late Holocene. Geology, 38(6), 511-514. doi:10.1130/G30729.1

Walsh, K.J.E.; McBride, J.L.; Klotzbach, P.J.; Balachndran, S.; Camargo, S.J.; Holland, G.J.; Knutson, T.R.; Kossin, J.P.; Lee, T.; Sobel, A.H., and Sugi, M., 2016. Tropical cyclones and climate change. WIREs: Climate Change, 7(1), 65-89. doi:10.1002/wcc.371

Warren, R.S. and Niering, W.A., 1993. Vegetation change on a northeast tidal marsh: Interaction of sea-level rise and marsh accretion. Ecology, 74(1), 96-103. doi:10.2307/1939504

Wood, M.E.; Kelley, J.T., and Belknap, D.F., 1989. Patterns of sediment accumulation in the tidal marshes of Maine. Estuaries, 12, 237-246. doi:10.2307/1351903

Woodruff, J.D.; Donnelly, J.P.; Mohrig, D., and Geyer, W.R., 2008. Reconstructing relative flooding intensities responsible for hurricane-induced deposits from Laguna Playa Grande, Vieques, Puerto Rico. Geology, 36(5), 391-394. doi:10.1130/G24731A.1 